\title{
PROFIL TEKSTUR DAN HEDONIK PEMPEK LENJER BERBAHAN LOKAL TEPUNG TALAS BOGOR (Colocasia esculenta L. Schott) DAN IKAN LELE DUMBO (Clarias gariepinus)
}

\section{[The Texture and Hedonic Profiles of Pempek Lenjer Made from Local Commodities of Bogor Taro Flour (Colocasia esculenta L. Schott) and African Catfish (Clarias gariepinus)]}

\author{
Aminullah*, Daniel, Titi Rohmayanti \\ Jurusan Teknologi Pangan dan Gizi, Fakultas Ilmu Pangan Halal, Universitas Djuanda \\ *Email korespondensi: aminullah@unida.ac.id
}

Diterima: 25 Agustus 2019

Disetujui : 10 Februari 2020

DOI: http://dx.doi.org/10.23960/jtihp.v24i1.7-18

\begin{abstract}
Pempek is one of the traditional foods of Southern Sumatra with the main ingredients of fish flesh and tapioca flour. The objective of the study was to determine the effect of the local commodities of Bogor taro flour and African catfish addition to the texture and hedonic profiles of pempek lenjer, as well as its protein and fiber content. The treatments were the comparison of tapioca and Bogor taro flours of $100 \mathrm{~g}: 0 \mathrm{~g}, 85 \mathrm{~g}: 15 \mathrm{~g}$, and $70 \mathrm{~g}: 30 \mathrm{~g}$, and the catfish flesh of $90 \mathrm{~g}, 100 \mathrm{~g}$, and $110 \mathrm{~g}$, respectively. Pempek lenjer was observed for the texture profiles of hardness, springiness, and stickiness, as well as for hedonic profiles of color, aroma, taste, and springiness texture. The results showed that the more use of Bogor taro flour and African catfish, the level of hardness of lenjer pempek decreased, and the level of springiness increased, but did not significantly affect the level of adhesiveness. The hedonic test showed that the addition of taro flour and catfish tended to have a low preference value on the parameters of aroma, taste, and springiness. However, the preference value of the color tended to have a higher preference. Based on the panelist preference, a combination of tapioca and taro flours of $85 \mathrm{~g}: 15 \mathrm{~g}$ and catfish of $100 \mathrm{~g}$ were selected in this study. This pempek lenjer had protein and fiber contents of $7.06 \%$ and $2.16 \%$, respectively.
\end{abstract}

Keywords: African catfish, Bogor taro flour, pempek lenjer, texture and hedonic profiles

\begin{abstract}
ABSTRAK
Pempek merupakan satu jenis panganan tradisional masyarakat daerah Sumatera Selatan dengan bahan utama daging ikan dan pati tapioka. Penelitian ini bertujuan untuk mengetahui pengaruh penambahan bahan lokal tepung talas Bogor dan ikan lele dumbo terhadap profil tekstur dan kesukaan pempek lenjer serta kadar protein dan seratnya. Penelitian menggunakan rancangan acak lengkap faktorial dengan perlakuan perbandingan pati tapioka dan tepung talas Bogor sebesar $100 \mathrm{~g}: 0 \mathrm{~g}, 85 \mathrm{~g}: 15 \mathrm{~g}$, dan $70 \mathrm{~g}: 30 \mathrm{~g}$ serta penggunaan daging ikan lele dumbo sebanyak $90 \mathrm{~g}, 100 \mathrm{~g}$, dan $110 \mathrm{~g}$. Pempek yang dihasilkan kemudian diuji profil tekstur yang meliputi kekerasan, kekenyalan, dan kelengketan serta uji kesukaan yang meliputi parameter warna, aroma, rasa, dan tekstur kekenyalan. Hasil kajian menunjukkan semakin banyak penggunaan tepung talas Bogor dan ikan lele dumbo, tingkat kekerasan pempek lenjer semakin menurun dan tingkat kekenyalan semakin meningkat, tetapi tidak berpengaruh nyata terhadap tingkat
\end{abstract}


kelengketan. Uji hedonik menunjukkan bahwa penambahan tepung talas dan ikan lele cenderung memiliki nilai kesukaan yang rendah pada aroma, rasa, dan tekstur kekenyalan walaupun nilai kesukaan terhadap parameter warna cenderung memiliki nilai kesukaan yang lebih tinggi. Uji hedonik menghasilkan kombinasi perlakuan perbandingan pati tapioka dan talas $85 \mathrm{~g}: 15 \mathrm{~g}$ dan ikan lele sebanyak $100 \mathrm{~g}$ sebagai perlakuan terpilih dalam penelitian ini. Pempek terpilih memiliki kadar protein dan serat pangan sebesar, berturutturut, $7,06 \%$ dan $2,16 \%$.

Kata kunci: ikan lele dumbo, pempek lenjer, profil tekstur dan kesukaan, tepung talas Bogor

\section{PENDAHULUAN}

Pempek adalah makanan produk pangan tradisional yang berasal dari daerah Sumatra Selatan, terutama Palembang. Pempek telah menjadi ikon pariwisata di daerah tersebut, seperti halnya gudeg dari Yogyakarta dan selat solo dari Solo (Pieniak et al., 2009). Pempek terdiri atas berberapa jenis diantaranya lenjer, kapal selam, keriting, adaan, tahu, pistel, dan pempek panggang. Pempek jenis lenjer adalah jenis pempek yang menggunakan adonan dasar tanpa tambahan apa pun. Berbeda dengan jenis pempek lainnya yang telah mengalami penambahan bahan seperti telur, santan, dan kulit ikan (Aprilianingtyas, 2009). Karneta et al. (2013) menjelaskan bahwa pempek dibuat dari dua bahan utama, yaitu bahan dasar daging ikan yang dihaluskan seperti ikan tenggiri, belida, dan gabus dan bahan pati tapioka yang ditambahkan garam, air, dan bumbu sebagai penguat cita rasa. Selain ikan tenggiri, beberapa jenis ikan lain juga dapat digunakan seperti ikan gabus (Fajri dan Dasir, 2017; Sugito dan Hayati, 2006), ikan mas (Erungan, 2007), dan ikan lele (Dasir dan Verayani, 2015; Hamdani, 2015).

Bogor merupakan salah satu kawasan minapolitan dengan produksi ikan lele yang meningkat setiap tahunnya. Menurut Ditjen Perikanan Budidaya Kementerian Kelautan dan Perikanan (2018), produksi ikan lele di Bogor mengalami peningkatan yang signifikan dari 441.217 ton menjadi 1.771.867 ton dari tahun 2012-2017. Menurut Nofitasari (2015), ikan lele dumbo memiliki kandungan protein yang tidak kalah dibandingkan dengan ikan tenggiri dan belida, selain jumlah produksinya tiap tahun meningkat, juga mudah diperoleh.

Selain ikan sebagai bahan utama dalam pembuatan pempek, tepung juga menjadi salah satu komponen yang penting dalam pembuatan pempek. Bogor memiliki beberapa komoditas lokal yang cukup terkenal dan unik, yang antara lain umbi talas. Rachmawan et al. (2013) melaporkan bahwa kadar karbohidrat pada tepung talas Bogor menyerupai tepung tapioka. Selain karbohidrat, kadar protein tepung talas Bogor lebih tinggi dibandingkan pati tapioka, yakni 4,69g/100g (Richana, 2012). Selain itu, Dinas Pertanian Kota Bogor (2018) melaporkan produksi talas Bogor mengalami kenaikan dari 1,34 ton pada tahun 2016 menjadi 1,687 ton pada tahun 2017. Pembuatan pempek dengan penambahan tepung talas dan penggunaan sumber ikan lele serta pengujian profil teksturnya belum banyak terpustakakan secara lengkap.

Berdasarkan beberapa penjelasan sebelumnya, maka penelitian ini bertujuan mempelajari profil tekstur dan kesukaan dari pempek lenjer yang dibuat dari pati tapioka dengan campuran tepung talas Bogor dan sumber ikan lele dumbo serta menguji kadar protein dan serat kasar pada pempek dengan formula terpilih. 


\section{BAHAN DAN METODE}

\section{Bahan dan Alat}

Bahan-bahan yang digunakan meliputi daging ikan lele dumbo, pati tapioka merek pak tani gunung, tepung talas Bogor merek Naya, air dan garam. Alat yang digunakan adalah wadah adonan, pengukus stainless steel, blender tipe HR2061/20 (Phillips Indonesia), dan termometer alkohol batang tipe S-006 (GEA) serta beberapa alat penunjang. Sedangkan, alat yang digunakan dalam analisis adalah Texture Analyzer TA-XT Plus tipe TexturePro CT V1.2 Build 9 (Stable Micro Systems, UK).

\section{Preparasi Sampel}

Proses pembuatan pempek merupakan modifikasi dari Aprilianingtyas (2009). Pembuatan pempek diawali dengan penyiangan ikan lele terhadap kulit, tulang dan kepala yang tidak digunakan kemudian dicuci bersih dari kotoran yang masih menempel pada daging. Daging ikan emudian digiling hingga halus. Daging ikan lele giling kemudian dicampur dengan $3 / 4$ bagian air dan $1 / 4$ bagian air lainnya untuk melarutkan garam (4\% dari bobot tepung) dengan penambahan total air sebanyak 40 g. Jumlah daging ikan lele sesuai dengan perlakuan penelitian yaitu proporsi $90 \mathrm{~g}, 100 \mathrm{~g}$, dan $110 \mathrm{~g}$. Larutan garam kemudian ditambahkan ke dalam campuran dan diuleni hingga rata sampai membentuk adonan. Adonan kemudian ditambahkan ke campuran tapioka dan tepung talas Bogor secara merata dengan total 100g. Adonan kemudian dibentuk silinder dengan panjang dan diameter, berturut-turut, sekitar $10 \mathrm{~cm}$ dan $3 \mathrm{~cm}$. Selanjutnya, pempek direbus selama 20 menit dalam air mendidih, lalu ditiriskan. Setelah sampel dingin, lalu dilakukan uji profil tekstur.

\section{Rancangan Percobaan}

Rancangan percobaan pada penelitian menggunakan Rancangan Acak Lengkap Faktorial 2 faktor dengan dua ulangan. Faktor pertama adalah proporsi pati tapioka dan talas Bogor dengan 3 taraf, yaitu 100:0; 85:15; dan 70:30. Sedangkan faktor kedua adalah bobot ikan lele dengan 3 level, yaitu bobot ikan lele $90 \mathrm{~g}, 100 \mathrm{~g}$, dan $110 \mathrm{~g}$.

\section{Uji Profil Tekstur}

Pengukuran sifat fisik pempek diukur dengan menggunakan STabel Micro System Texture Analyzer TA-XT Plus tipe TexturePro CT V1.2 Build 9. Alat Texture Analyzer dilengkapi dengan sistem komputerisasi dan jenis probe. Probe yang digunakan adalah Warner-Bratzler Blade $\mathrm{P} / 35$ berdiameter probe $35 \mathrm{~mm}$ dengan pengaturan probe set TA4/1000, fixture TA -BT-KI, load cell $4500 \mathrm{~g}$, pretest speed 2 $\mathrm{mm} / \mathrm{s}$, date rate 10 points/s, trigger load $4,5 \mathrm{~g}$, dan test speed $0,5 \mathrm{~mm} / \mathrm{s}$.

Sebanyak 18 sempel pempek lenjer yang sudah disiapkan dipotong dengan dimensi panjang, lebar, dan tinggi $1,5 \mathrm{~cm}$. Ketika alat dioperasikan, probe akan memberi gaya tekan atau kompresi pada sampel. Semakin besar resistensi untuk deformasi, maka semakin keras, kenyal, dan lengket tekstur produk pempek. Hasil ditunjukan berupa angka pada monitor komputer yang akan dibagi menjadi tiga bagian yaitu, nilai kekerasan, nilai kekenyalan, dan nilai kelengketan.

\section{Uji Hedonik/Kesukaan (Soekarto, 1995)}

Uji hedonik merupakan uji yang dilakukan untuk menilai tingkat kesukaan panelis terhadap produk pempek lenjer sesuai perlakuan. Pempek yang diujikan adalah pempek lenjer yang telah direbus tanpa proses penggorengan dan penggunaan cuka. Panelis pada uji ini sebanyak 30 panelis semi terlatih yang memiliki pengetahuan tentang produk 
pempek sebelumnya untuk menilai parameter aroma, warna, rasa, dan tekstur kekenyalan produk. Skor hedonik memiliki nilai yang naik berdasarkan tingkat kesukaan dengan rentang 0 sampai 10 , yaitu tidak suka $=0$ dan suka $=10$.

\section{Penentuan Pempek Terpilih}

Penentuan pempek terpilih diperoleh berdasarkan hasil uji hedonik, uji kekerasan, uji kelengketan, dan uji kekenyalan. Pempek terpilih kemudian dianalisis kadar protein dan kadar serat pangannya.

\section{Analisis Kadar Protein (Metode Mikro Kjeldahl; AOAC, 2005)}

Satu gram sampel dimasukkan ke dalam labu Kjel Digester. Kemudian $1 \mathrm{~g}$ campuran selenium dan $12 \mathrm{ml} \mathrm{H}_{2} \mathrm{SO}_{4}$ pekat ditambahkan ke dalam labu lalu didestruksi selama 120 menit dengan suhu $420^{\circ} \mathrm{C}$. Cairan dibiarkan dingin dalam labu destruksi, kemudian $50 \mathrm{ml} \mathrm{NaOH} \mathrm{40 \% ,} 3$ tetes indikator PP $1 \%$, dan $25 \mathrm{ml}$ air suling ditambahkan dan selanjutnya campuran dipindahkan ke alat destilasi. Proses destilasi mengunakan alat Buchi Distillation unit K-355 hingga memperoleh tiga kali volume penambahan asam borat $4 \%$, dengan pemapungan awal $50 \mathrm{ml}$. Hasil destilasi kemudian dilakukan titrasi dengan larutan $\mathrm{HCl}$ 0,2 $\mathrm{N}$ hingga memperoleh titik akhir menjadi merah. Prosedur blanko dilakukan seperti di atas tanpa penambahan sampel pempek lenjer. Kadar protein dihitung sebagai berikut:

$$
\text { Protein }=\left(\frac{(a-b) \times N \times 14,007 \times 6,25}{m g \text { contoh }}\right) \times 100 \%
$$

Keterangan:

$\mathrm{a}=$ jumlah larutan $\mathrm{HCl}$ untuk mentitrasi contoh (ml)

$\mathrm{b}=$ jumlah larutan $\mathrm{HCl}$ untuk mentitrasi blanko (ml)

$\mathrm{N}=$ normalitas larutan $\mathrm{HCl}$
Analisis Kadar Serat Pangan (Metode Enzimatis; Asp et al., 1983)

Proses digesi diawali dengan menimbang sampel pempek sebanyak 1 gram, lalu dimasukkan ke dalam Erlenmeyer, ditambahkan $25 \mathrm{ml}$ buffer natrium fosfat 0,1 M pH 6 dan diaduk. Enzim termamyl sebanyak $0,1 \mathrm{ml}$ ditambahkan ke dalam Erlenmeyer, lalu ditutup dengan alumunium foil dan diinkubasi dalam penangas air bersuhu $100^{\circ} \mathrm{C}$ selama 15 menit, lalu dibiarkan dingin. Setelah itu ditambahkan $20 \mathrm{ml}$ air destilata dan pHnya diatur menjadi 1,5 menggunakan $\mathrm{HCl}$. Setelah ditambahkan $100 \mathrm{mg}$ pepsin, Erlenmeyer ditutup dan diinkubasikan dalam penangas air bergoyang pada suhu $40^{\circ} \mathrm{C}$ selama 60 menit. Air destilata ditambahkan sebanyak $20 \mathrm{ml}$ lalu pHnya diatur menjadi 6,8 menggunakan $\mathrm{NaOH}$. Pankreatin ditambahkan sebanyak $100 \mathrm{mg}$ kemudian Erlenmeyer ditutup dan diinkubasikan dalam penangas air bergoyang pada suhu $40^{\circ} \mathrm{C}$ selama 60 menit. $\mathrm{pH}$ diatur menjadi 4,5 menggunakan $\mathrm{HCl}$, kemudian disaring menggunakan crucible (porositas 2) yang diketahui beratnya dan mengandung 0,5 celite kering, dan selanjutnya dicuci 2 kali dengan $10 \mathrm{ml}$ air destilata.

$$
\text { Total serat pangan dapat }
$$
diendapkan langsung dengan cara menambahkan 4 volume etanol $95 \%$ ke dalam hasil digesi. Larutan disaring dengan crucible (porositas 2) yang telah diketahui beratnya dan mengandung $0,5 \mathrm{~g}$ celite kering, kemudian dicuci 2 kali dengan 10 $\mathrm{ml}$ etanol 95\%, dan 2 kali dengan $10 \mathrm{ml}$ aseton. Endapan dikeringkan pada suhu $105^{\circ} \mathrm{C}$ sampai beratnya tetap (semalam) dan ditimbang setelah didinginkan dalam desikator (D). Pengabuan dilakukan pada suhu $550^{\circ} \mathrm{C}$ selama 5 jam, didinginkan dalam desikator dan ditimbang setelah dingin (I). Kadar total serat dihitung dengan rumus sebagai berikut:

$$
\text { Total serat }(\% b b)=\left(\frac{D-I-B}{W}\right) \times 100 \%
$$


Keterangan:

$\mathrm{W}=$ Berat sampel $(\mathrm{g})$

$\mathrm{D}=$ Berat setelah pengeringan $(\mathrm{g})$

$\mathrm{I}=$ Berat setelah pengabuan $(\mathrm{g})$

$\mathrm{B}=$ Berat blanko bebas abu $(\mathrm{g})$

\section{Analisis Data}

Data hasil uji profil tekstur dan hedonik dalam penelitian dianalisis sidik ragamnya (ANOVA) melalui perangkat lunak SPSS ${ }^{\circledR}$ 16.0. for Windows. Jika terdapat perbedaan yang signifikan maka dilanjutkan dengan uji lanjut Duncan pada taraf 5\%.

\section{HASIL DAN PEMBAHASAN}

Penambahan tepung talas dan jumlah ikan lele dumbo dengan sifat kimia dan fisiknya menghasilkan profil tekstur produk pempek lenjer seperti tingkat kekerasan, kekenyalan, dan kelengketan yang dapat dilihat pada Tabel 1 .

Tabel 1. Nilai kekerasan, kekenyalan, dan kelengketan pempek lenjer

\begin{tabular}{cccc}
\hline Sampel & $\begin{array}{c}\text { Kekerasan } \\
(\mathrm{gF})\end{array}$ & $\begin{array}{c}\text { Kekenyal } \\
\text { an }(\mathrm{mm})\end{array}$ & $\begin{array}{c}\text { Kelengket } \\
\text { an }(\mathrm{mJ})\end{array}$ \\
\hline A1B1 & $1985,25^{\mathrm{ab}}$ & $3,245^{\mathrm{a}}$ & $0,075^{\mathrm{a}}$ \\
A2B1 & $1914,25^{\mathrm{ab}}$ & $3,385^{\mathrm{ab}}$ & $0,010^{\mathrm{a}}$ \\
A3B1 & $1823,75^{\mathrm{abc}}$ & $3,575^{\mathrm{bc}}$ & $0,060^{\mathrm{a}}$ \\
A1B2 & $2096,75^{\mathrm{a}}$ & $3,480^{\mathrm{b}}$ & $0,000^{\mathrm{a}}$ \\
A2B2 & $1743,00^{\mathrm{bcd}}$ & $3,570^{\mathrm{bc}}$ & $0,000^{\mathrm{a}}$ \\
A3B2 & $1487,50^{\mathrm{d}}$ & $3,710^{\mathrm{c}}$ & $0,025^{\mathrm{a}}$ \\
A1B3 & $1766,25^{\mathrm{bcd}}$ & $2,975^{\mathrm{d}}$ & $0,000^{\mathrm{a}}$ \\
A2B3 & $2000,50^{\text {ab }}$ & $3,570^{\mathrm{bc}}$ & $0,020^{\mathrm{a}}$ \\
A3B3 & $1575,50^{\text {cd }}$ & $3,465^{\mathrm{b}}$ & $0,035^{\mathrm{a}}$ \\
\hline
\end{tabular}

Keterangan:

$\mathrm{A} 1=$ Bobot ikan lele $90 \mathrm{~g}$

$\mathrm{A} 2=$ Bobot ikan lele $100 \mathrm{~g}$

$\mathrm{A} 3=$ Bobot ikan lele $110 \mathrm{~g}$

$\mathrm{B} 1=$ Proporsi pati tapioka dan talas 100:0

$\mathrm{B} 2=$ Proporsi pati tapioka dan talas $85: 15$

B3 = Proporsi pati tapioka dan talas 70:30

Notasi huruf yang berbeda pada satu kolom menyatakan berbeda nyata dengan uji Duncan pada nilai $\alpha 0,05$
Uji Kekerasan

Tabel 1 menunjukkan bahwa penambahan bobot ikan lele memiliki kecenderungan menurunkan tingkat kekerasan pempek lenjer yang dibuat dari penambahan tepung talas, tetapi tidak berbeda pada pempek yang dibuat dari $100 \%$ tapioka. Anguilar et al. (1997) menjelaskan penambahan jumlah daging ikan pada pempek akan meningkatkan kadar air pada produk sehingga menurunkan nilai kekerasan pempek. Selain itu, Setyowati dan Choirunnisa (2014) dan Aprilianingtyas (2009) juga melaporkan bahwa kadar air dalam bahan mempengaruhi nilai kekerasan pempek, semakin banyak kadar air dalam suatu produk maka nilai kekerasannya semakin menurun.

Pengaruh penambahan tepung talas tergantung pada jumlah iken lele yang ditambahkan (Tabel 1). Menurut Ulfa (2018) perbedaan tingkat kekerasan erat kaitannya dengan kadar amilosa, semakin tinggi kadar amilosa pada bahan akan mampu meningkatkan kekerasan pada produk yang dihasilkan. Harris (2001) melaporkan bahwa pati tapioka memiliki kadar amilosa sebanyak 17,41\%, sedangkan kadar amilosa pada tepung talas Bogor sebanyak 16,5\% Hartati dan Titik (2003). Data ini mengindikasikan bahwa kandungan amilosa kedua tepung tersebut mendekati sama sehingga tingkat kekerasan pada pempek lenjer yang dihasilkan tidak berbeda antara pati tapioka $100 \%$ dan pati tapioka yang dicampur dengan tepung talas Bogor pada perlakuan ikan lele $90 \mathrm{~g}$ dan $100 \mathrm{~g}$. Namun pada pempek dengan ikan lele yang tinggi $(110 \mathrm{~g})$, penambahan tepung talas Bogor cenderung menurunkan tingkat kekerasan pempek lenjer yang dihasilkan. Hal ini menunjukkan bahwa daging ikan lele memberikan sinergisitas semakin banyak daging ikan lele dan penambahan tepung talas cenderung untuk menurunkan tingkat kekerasan pempek lenjer yang dihasilkan. 


\section{Uji Kekenyalan}

Kekenyalan dinyatakan dari tekanan atau kompresi pertama ketika bahan ditekan dan kembali pada bentuk semula, jarak tekanan kemudian dinyatakan dalam satuan milimeter. Nilai gaya yang diperoleh menunjukkan bahwa semakin besar nilainya maka semakin kenyal tingkat kekenyalan pempek. Tabel 1 menunjukkan bahwa penggunaan daging ikan lele dumbo yang semakin banyak menyebabkan kecenderungan pada meningkatnya tingkat kekenyalan pempek untuk semua variasi tepung talas. Menurut Tanikawa (2000), molekul-molekul protein akan berikatan dengan ikatan hidrogen dan disulfida membentuk konstruksi jala yang saling berikatan sehingga terbentuk gel yang membuat teksturnya kenyal. Namun demikian, nilai kekenyalan pempek yang dihasilkan yang berkisar antara 2,975$3,710 \mathrm{~mm}$ tergolong rendah. Hal ini dijelaskan oleh Yakhin et al. (2015) yang melaporkan bahwa ikan lele adalah jenis ikan air tawar yang memiliki kandungan lemak dan protein sarkoplasmik yang tinggi sehingga kapasitas pembentuk gelnya cukup rendah.

Penambahan tepung talas pada pembuatan pempek lenjer ikan lele memperlihatkan kecenderungan yang menurunkan kekenyalan pempek.. Perubahan pada nilai kekenyalan produk pempek lenjer yang terjadi dapat diakibatkan oleh kadar protein dan amilopektin tepung talas. Nilai protein tepung talas Bogor lebih tinggi, yaitu 4,69 g/ 100 g (Richana, 2012) dibandingkan dengan pati tapioka sebesar $0,5 \mathrm{~g} / 100 \mathrm{~g}$ (Direktorat Gizi Departemen Kesehatan RI, 1981) dapat menyebabkan kecenderungan tingkat kekenyalan yang semakin tinggi dengan penambahan tepung talas Bogor. Hal ini pun didukung oleh Tanikawa (2000) tentang pengaruh protein terhadap kenyalnya tekstur produk. Selain itu, kadar amilopektin pada tepung talas lebih rendah dibandingkan pati tapioka, yaitu 71,43\% (Aryanti et al., 2017) berbanding 77-80\% (Moorthy, 2004), berturut-turut. Sehingga perlakuan penambahan ikan dan pati tapioka yang dicampur tepung talas Bogor menunjukan pengaruh nyata terhadap tingkat kekenyalan pempek yang dihasilkan $(p<0,05)$, yaitu semakin banyak penambahan tepung talas dan daging ikan lele, menghasilkan pempek lenjer dengan tingkat kekenyalan yang lebih tinggi.

\section{Uji Kelengketan}

Kelengketan dinyatakan sebagai usaha yang diperlukan untuk menahan tekanan yang timbul diantara permukaan objek dan permukaan benda lain saat terjadi kontak antara objek dengan benda, yang dinyatakan dalam satuan mili Joule. Tabel 1 menunjukkan bahwa penggunaan tepung talas Bogor dan ikan lele dumbo yang semakin banyak tidak berpengaruh terhadap nilai kelengketan pempek lenjer. Nilai kelengketan yang dihasilkan memiliki rentang 0,000 hingga $0,075 \mathrm{~mJ}$. Suyanti (2008) menjelaskan bahwa penambahan tepung atau pati tapioka bertujuan untuk memperbaiki tekstur, meningkatkan kelembutan, membantu pengembangan pada pori, dan memudahkan penanganan. Sedangkan menurut Richana (2012), karakteristik tepung talas yang tidak memiliki gluten menyebabkan produk yang dihasilkan tidak mengembang dan teksturnya tidak lengket. Penambahan ikan lele tidak mempengaruhi tingkat kelengketan pada pempek hal tesebut dijelaskan oleh Utomo et al. (2013) karena ikan lele tergolong dalam air tawar yang memiliki daging ikan berkadar lemak tinggi. Nessianti (2015) menyatakan ikan yang berlemak tinggi, kemampuan gel dan daya lengketnya kurang baik.

\section{Uji Hedonik}

Selain mempengaruhi profil tekstur yang terbentuk, penambahan tepung talas dan ikan lele dumbo menyebabkan 
perubahan pada penilaian kesukaan panelis khususnya pada atribut warna, aroma, rasa, dan kekenyalan pempek lenjer yang dihasilkan. Profil kesukaan pempek lenjer dapat dilihat pada Tabel 2.

Tabel 2. Nilai kesukaan pada parameter warna, aroma, rasa, dan kekenyalan pempek lenjer

\begin{tabular}{ccccc}
\hline Sampel & Warna & Aroma & Rasa & $\begin{array}{c}\text { Kekenya- } \\
\text { lan }\end{array}$ \\
\hline A1B1 & $4,5^{\text {ab }}$ & $4,5^{\text {ab }}$ & $4,0^{\mathrm{a}}$ & $4,6^{\text {de }}$ \\
A1B2 & $5,7^{\text {bc }}$ & $4,5^{\text {ab }}$ & $5,1^{\mathrm{c}}$ & $4,8^{\text {d }}$ \\
A1B3 & $5,6^{\text {bc }}$ & $4,8^{\text {bc }}$ & $4,8^{\mathrm{b}}$ & $4,4^{\mathrm{e}}$ \\
A2B1 & $5,8^{\mathrm{c}}$ & $4,7^{\mathrm{bc}}$ & $4,8^{\mathrm{b}}$ & $4,9^{\text {cd }}$ \\
A2B2 & $6,8^{\mathrm{c}}$ & $5,6^{\mathrm{d}}$ & $5,9^{\mathrm{g}}$ & $5,7^{\mathrm{a}}$ \\
A2B3 & $6,4^{\mathrm{c}}$ & $5,2^{\mathrm{cd}}$ & $5,2^{\mathrm{d}}$ & $5,7^{\mathrm{a}}$ \\
A3B1 & $5,7^{\mathrm{bc}}$ & $4,5^{\mathrm{ab}}$ & $5,9^{\mathrm{g}}$ & $4,0^{\mathrm{f}}$ \\
A3B2 & $6,1^{\mathrm{c}}$ & $4,6^{\mathrm{ab}}$ & $5,7^{\mathrm{f}}$ & $5,1^{\mathrm{bc}}$ \\
A3B3 & $3,9^{\mathrm{a}}$ & $4,1^{\mathrm{a}}$ & $5,4^{\mathrm{e}}$ & $5,3^{\mathrm{b}}$ \\
\hline
\end{tabular}

Keterangan:

A1 $=$ Bobot ikan lele $90 \mathrm{~g}$

$\mathrm{A} 2=$ Bobot ikan lele $100 \mathrm{~g}$

A3 = Bobot ikan lele $110 \mathrm{~g}$

$\mathrm{B} 1=$ Proporsi pati tapioka dan talas 100:0

$\mathrm{B} 2=$ Proporsi pati tapioka dan talas 85:15

B3 = Proporsi pati tapioka dan talas 70:30

Notasi huruf yang berbeda pada satu kolom menyatakan berbeda nyata dengan uji Duncan pada nilai $\alpha 0,05$

Tabel 2 menunjukkan terdapat interaksi antara bobot daging ikan lele dan proporsi tepung terhadap penilaian hedonik pada parameter warna, aroma, rasa, dan kekenyalan pempek lenjer dengan taraf kepercayaan 5\%. Interaksi ini memperlihatkan bahwa terdapat kecenderungan dengan semua taraf proporsi tepung dengan bobot ikan lele $100 \mathrm{~g}$ memiliki tingkat kesukaan pada semua parameter yang lebih tinggi dibandingkan bobot yang lain.

Selain itu, Tabel 2 juga menunjukkan bahwa proporsi tepung tapioka dan talas 85:15 dengan semua bobot ikan lele menghasilkan kesukaan pada warna, aroma, rasa, dan kekenyalan pempek lenjer yang cenderung lebih tinggi dibandingkan dengan proporsi yang lainnya. Sehingga dapat disimpulkan bahwa proporsi tepung tapioka dan talas dengan bobot ikan lele yang digunakan $100 \mathrm{~g}$ memiliki nilai kesukaan yang cenderung paling tinggi.

\section{Warna}

Tabel 2 menunjukkan bahwa panelis memiliki kecenderungan lebih menyukai warna pempek pada penggunaan ikan lele yang lebih banyak terutama pada ikan lele $100 \mathrm{~g}$ dibandingkan dengan bobot yang lainnya. Penambahan komposisi daging ikan lele pada pembuatan pempek sangat berpengaruh dikarenakan warna dasar yang putih dari daging ikan tersebut di mana semakin banyak penggunaan daging ikan lele membuat pempek semakin terang. Yulientin (2006) dan Wijayanti et al. (2012) menjelaskan bahwa warna dasar daging ikan lele adalah putih karena memiliki kandungan myoglobin rendah yang menyebabkan warna produk semakin terang.

Tabel 2 juga memberikan informasi bahwa penambahan tepung talas yang semakin banyak cenderung menurunkan kesukaan panelis terhadap pempek lenjer ikan lele dan penambahan tepung talas sebanyak $15 \mathrm{~g}$ (dalam jumlah cukup sedikit) cenderung lebih disukai. Hal ini dijelaskan Prihatiningrum (2011), senyawa saponin pada tepung talas akan mengalami perubahan warna menjadi coklat gelap jika dilakukan proses pemanasan. Selain itu, juga dapat dilihat bahwa pempek lenjer dengan penambahan tepung talas $30 \mathrm{~g}$ dan ikan lele dumbo $110 \mathrm{~g}$ adalah pempek yang paling tidak disukai oleh panelis.

\section{Aroma}

Hikmawati et al. (2017) melaporkan bahwa penambahan daging ikan lele yang terlalu banyak pada pembuatan dim sum menyebabkan aroma spesifik ikan lele semakin jelas sehingga penelis kurang me- 
nyukainya. Laiya et al. (2014) juga menjelaskan bahwa aroma khas ikan akan cenderung menutupi aroma khas dari bahan tambahan yang dicampurkan dalam pembuatan suatu produk.

Tepung talas Bogor dan tapioka tidak mempunyai rasa dan aroma, sehingga pada penggunaan pati tapioka dan tepung talas untuk semua perlakuan penambahan ikan lele pada parameter aroma tidak berpengaruh nyata. Pernyataan tersebut diperkuat pula oleh hasil penelitian Ulfa (2018), menyatakan bahwa penambahan tepung talas Bogor tidak berpengaruh terhadap respon panelis pada parameter aroma.

\section{Rasa}

Tabel 2 menunjukkan tingkat kesukaan panelis cenderung semakin meningkat dengan penambahan daging ikan lele yang banyak terhadap parameter rasa untuk semua perlakuan tepung talas. Menurut Aprilianingtyas (2009), rasa khas ikan sulit untuk dihilangkan dalam pembuatan pempek. Saparudin dan Murtado (2017) menyatakan panelis di kota Palembang dominan menyukai pempek dengan rasa amis khas ikan. Hikmawati et al. (2017) menjelakan pula bahwa semakin banyak jumlah ikan lele yang digunakan akan menghasilkan rasa yang gurih dan khas ikan yang sangat kuat dan cenderung disukai oleh para panelis. Namun demikian tingkat kesukaan tergantung pada jumlah tepung talas yang ditambahkan.

Penambahan tepung talas yang lebih banyak (30 g) menurunkan kembali tingkat kesukaan panelis terhadap rasa pempek. Putri (2013) melaporkan semakin tinggi persentasi penggunaan tepung talas maka akan meningkatkan rasa khas talas itu sendiri. Data ini menjelaskan bahwa rasa khas talas dalam jumlah sedikit dalam pempek lenjer dapat menjadi hal yang menarik bagi panelis. Interaksi antara penambahan tepung talas dan penggunaan ikan lele dumbo menghasilkan bahwa te- pung talas $15 \mathrm{~g}$ dan ikan lele $100 \mathrm{~g}$ merupakan perlakuan yang paling disukai panelis dalam hal rasa pempek.

\section{Tekstur Kekenyalan}

Tabel 2 menunjukan penggunaan ikan lele yang banyak cenderung memberikan respon kesukaan panelis terhadap tekstur kekenyalan pempek yang bergantung pada level perlakuan tepung talas. Penggunaan penambahan tepung talas Bogor yang lebih banyak memberikan respon kesukaan yang lebih tinggi terhadap parameter tekstur kekenyalan. Hal tersebut sesuai dengan pengujian profil tekstur kekenyalan, yang menjelaskan bahwa penambahan daging ikan lele dan tepung talas pada jumlah yang banyak meningkatkan kekenyalan produk pempek.

Daging lele yang kaya akan protein sekitar 17\% - 22\% (Rosa et al, 2007) akan berikatan dengan senyawa lainnya membentuk konstruksi jala yang saling berikatan yang menyebabkan tekstur produk menjadi kenyal (Tanikawa, 2000). Selain itu, Ririsanti et al. (2017) melaporkan penggunaan karagenan dapat membantu untuk meningkatkan kesukaan terhadap kekeyalan pempek.

Kusnandar et al. (2007) melaporkan bahwa kekuatan gel ebih banyak ditentukan oleh kadar amilosanya sehingga kadar amilosa yang semakin tinggi akan meningkatkan kemampuan membentuk gel dan lapisan film. Selain itu, protein tepung talas yang tinggi dibandingkan pati tapioka sebesar, berturut-turut, 4,69 g/ $100 \mathrm{~g}$ bahan (Richana, 2012) dan 0,5 g/100 g bahan (Direktorat Gizi Departemen Kesehatan RI, 1981).

\section{Analisis Kimia Pempek Terpilih}

Kombinasi perlakuan perbandingan pati tapioka dan tepung talas sebesar $85 \mathrm{~g}: 15 \mathrm{~g}$ dan penggunaan ikan lele dumbo sebesar 100 g merupakan kombinasi perlakuan terpilih yang berdasarkan tingkat kesukaan panelis pada produk pempek len- 
jer. Produk terpilih selanjutnya dilakukan analisis kimia meliputi kadar protein dan serat pangan. Data hasil pengujian dapat dilihat pada Tabel 3.

Tabel 3. Uji kadar protein dan serat pangan pempek terpilih dan pempek lainnya

\begin{tabular}{lcc}
\hline \multicolumn{1}{c}{ Pempek } & \multicolumn{2}{c}{ Karakteristik kimia $(\% \mathrm{~b} / \mathrm{b})$} \\
& Protein & Serat pangan \\
\hline Talas lele & 7,06 & 2,15 \\
SNI $^{1)}$ & 6,47 & 2,12 \\
Ikan gabus $^{2)}$ & 5,41 & 1,60 \\
Ikan nila $^{3)}$ & 3,43 & - \\
Ikan mas $^{4)}$ & 4,12 & - \\
Ikan sapu-sapu $^{4}$ & 2,88 & 1,73 \\
Ikan lele $^{6)}$ & 5,41 & - \\
Ikan cakalang $^{7)}$ & 10,29 & - \\
\hline
\end{tabular}

Keterangan: ${ }^{1)}$ SNI 7661:2013 tentang Pempek Ikan Rebus Beku; ${ }^{2)}$ Aprilianingtyas (2009); ${ }^{3)}$ Diyantoro (2002); ${ }^{4)}$ Erungan (2007); ${ }^{5)}$ Trisnawati (2007); ${ }^{\text {) }}$ Hamdani (2015); ${ }^{7}$ Talib dan Marlena (2015)

Kadar protein yang terkandung pada pempek terpilih memiliki nilai sebesar $7,06 \%$. Kandungan protein pada pempek ikan lele dengan penambahan tepung talas Bogor dan pati tapioka ini memiliki kadar yang lebih tinggi dibandingkan dengan pempek lain dengan penggunaan bahan ikan yang berbeda, dan juga melebihi standar SNI, Tingginya kadar protein pada pempek berasal ikan lele yang memiliki kadar protein yang tinggi, yaitu sekitar $17 \%-22 \%$ dan tepung talas $4,69 \%$ (Richana, 2012).

\section{Serat Pangan}

Kadar serat pangan pada perlakuan pempek terpilih sebesar 2,16\% sedangkan pada SNI, pempek ikan gabus dan pempek ikan sapu-sapu serat pangan sebesar, berturut-turut, $2,12 \%, 1,60 \%$, dan $1,73 \%$. Tingginya nilai serat yang dihasilkan dijelaskan oleh Richana (2012) bahwa tepung talas memiliki kadar serat kasar sebesar 2,69\%.

\section{KESIMPULAN}

Semakin banyak penambahan ikan lele dumbo dan tepung talas menyebabkan kecenderungan semakin rendah tingkat kekerasan dan semakin tinggi tingkat kekenyalan pempek lenjer yang dihasilkan, akan tetapi tidak berpengaruh nyata terhadap tingkat kelengketan. Penggunaan ikan lele dan tepung talas menghasilkan nilai kesukaan yang rendah terhadap aroma, rasa, dan tekstur kekenyalan, akan tetapi cukup tinggi pada parameter warna pempek lenjer. Pempek terpilih dalam penelitian ini adalah pempek dengan perlakuan perbandingan pati tapioka dan talas 85g:15g dan ikan lele sebanyak $100 \mathrm{~g}$. Pempek terpilih memiliki kadar protein dan serat pangan sebesar, berturut-turut, 7,06\% dan $2,16 \%$.

\section{UCAPAN TERIMA KASIH}

Penelitian ini didukung oleh Hibah Dana Internal Perguruan Tinggi, Universitas Djuanda Bogor dengan nomor kontrak 259/LPPM/K-VI/2019.

\section{DAFTAR PUSTAKA}

Anguilar, C., N. A. Anzaldua-Morales, R. Tamalas, and G. Gastelum. 1997. Low temperatur blanch improves textural quality of french fries. Journal Food Science. 62: 568-569.

Aprilianingtyas, Y. 2009. Pengembangan Produk Pempek Palembang dengan Penambahan Sayuran Bayam dan Wortel Sebagai Serat Pangan. (Skripsi). Institut Pertanian Bogor. Bogor.

Aryanti, N., Y.A. Kusumastuti, dan W. Rahmawati. 2017. Pati talas (Colocasia esculenta (L.) Schott) sebagai alternatif sumber pati industri. Momentum. 13(1): 46-52.

Asp, N.G., C.G. Johansson, H. Halmer, and M. Siljestrom. 1983. Rapid enzymatic assay of insoluble and soluble dietary 
fiber. Journal of Agricultural and Food Chemistry. 31: 476-482.

[AOAC] Association of Official Analytical Chemist. 2005. Official Methods of Analysis (18 Edn). Association of Official Analytical Chemist Inc. Mayland, USA.

Dasir, A.D.M, and A. Verayani. 2015. Ability of coating material in maintaining empek-empek quality during vacum storage. Food Science and Quality Management. 44: 36-41.

[Disperta] Dinas Pertanian Kota Bogor. 2018. Target dan Realisasi Produksi Palawija di Kota Bogor. Dinas Pertanian. Bogor.

Direktorat Gizi Departemen Kesehatan RI. 1981. Daftar Komposisi Bahan Makanan. Bhatara Karya Aksara. Jakarta.

Diyantoro, C. 2002. Pemanfaatan Kaldu Kepala Udang Windu (Penaeus monodon) Sebagai Flover Terhadap Mutu Empek-Empek Dari Ikan Nila (Oreochromis niloticus). (Skripsi). Institut Pertanian Bogor. Bogor.

[Ditjen-DKP] Ditjen Perikanan Budidaya Kementerian Kelautan dan Perikanan. 2018. Data dan Laporan Statistik Perikanan Budidaya. Kementerian Kelautan dan Perikanan. Jakarta.

[DSN] Dewan Standarisasi Nasional. 1995. SNI 7661:2013 tentang Pempek Ikan Rebus Beku. Dewan Standarisasi Nasional. Jakarta.

Erungan, C. 2007. Pengaruh Penambahan Tepung Tapioka Dan Jenis Ikan Terhadap Mutu Empek-Empek. (Skripsi). Institut Pertanian Bogor. Bogor.

Fajri, M., dan Dasir. 2017. Studi tenggang waktu penggunaan daging ikan gabus pada pembuatan pempek lenjer. Edible. 6(1): 20-26.

Hamdani, M. 2015. Karakteristik Mutu Surimi Segar Ikan Lele Dumbo (Clarias gariepinus) dan Aplikasinya
Untuk Pembuatan Empek-Empek. (Skripsi). Institut Pertanian Bogor. Bogor.

Harris, H. 2001. Kemungkinan penggunaan edible film dari pati tapioka untuk pengemas lempuk. Jurnal Ilmu-Ilmu Pertanian Indonesia. 3(2): 99-106.

Hartati, S.N. dan K.P. Titik. 2003. Analisis Kadar Pati dan Serat Kasar Tepung Beberapa Kultivar Talas. Pusat Penelitian Bioteknologi LIPI. Bogor.

Hikmawati, L., N. Kurniawati, I. Rostini, dan E. Liviawaty. 2017. Pemanfaatan surimi ikan lele dalam pembuatan dim sum terhadap kesukaan. Jurnal Perikanan dan Kelautan. 8(1): 64-72.

Karneta, R., A. Rejo, G. Priyanto, dan R. Pambayun. 2013. Difusivitas panas dan umur simpan pempek lenjer. Jurnal Keteknikan Pertanian. 27:131141.

Kusnandar F, L. Nuraida, dan N.S. Palupi. 2007. Pemanfaatan Talas, Garut, dan Sukun sebagai Prebiotik dan Formulasi Simbiotik sebagai Suplemen Pangan. Institut Pertanian Bogor. Bogor.

Laiya,N.,RM Harmain, dan N. Yusuf. 2014. Formulasi kerupuk ikan gabus yang disbstitusi dengan tepung sagu. Jurnal Ilmiah Perikanan dan Kelautan 2(2):81-87

Moorthy, S.N. 2004. Tropical sources of starch. In: Eliasson, A.C. (ed). Starch in Food: Structure, Function, and Application. CRC Press. Florida

Nessianti, T. 2015. Fish and Krill Protein. Processing Technology. Applied Sci. Publ. London

Nofitasari, N.,Baidar, dan W. Syarif. 2015. Pengaruh Penggunaan Jenis Ikan yang Berbeda Terhadap Kualitas Pempek. E -Journal Home Economic and Tourism 10(3):1-18.

Pieniak, Z., W. Verbeke, F. Vanhonacker, L. Guerrero, and M. Hersleth. 2009. 
Association between traditional food consumption and motives for food choice in six European countries. Appetite Journal. 53: 101-108.

Prihatiningrum. 2011. Pengaruh Komposit Tepung Kimpul dan Tepung Terigu Terhadap Kualitas Cookies Semprit. Food Science and Culinary Education Journal 1(1): 6-12.

Putri, R. 2013. Pengaruh Substitusi Tepung Talas Belitung (Xanthosoma sagittifolium) Terhadap Tingkat Pengembangan dan Daya Terima Donat. (Skripsi). Universitas Muhammadiyah Surakarta. Surakarta.

Rachmawan, O., A. Taofik, dan N. Suwarno. 2013. Penggunaan Tepung Talas Bogor (Colocasia esculenta L. Schott) Terhadap Sifat Fisik dan Akseptabilitas Nagget Ayam Petelur Afkir. Jurnal Istek 7(2):152-162.

Richana, N. 2012. Ubi Kayu dan Ubi Jalar. Nuansa Cendikiawa. Bandung.

Ririsanti, N.N, E. Liviawaty, Y.N. Ihsan, dan R.I. Pratama. 2017. Penambahan karagenan terhadap tingkat kesukaan pempek lele. Jurnal Perikanan dan Kelautan. 8(1): 165-173.

Rosa, R., N.M. Bandara, and M.L. Nunes. 2007. Nutritional quality of African catfish (Clarias gariepinus): a positive criterion for the future development of the European production of Silurodei. International Journal of Food Science and Technology. 42: 342-351.

Saparudin, A. dan A.D. Murtado. 2017. Karakteristik kimia, fisika dan sensoris pempek lenjer kering dengan konsentrasi $\mathrm{CaCl}_{2}$, Edible 6(1):1-5

Setyowati, W.T dan F. Choirunnisa. 2014. Formulasi biskuit tinggi serat (kajian proporsi bekatul jagung:tepung terigu dan penambahan baking powder). Jurnal Pangan dan Agroindustri. 2(3): 224-231.

Soekarto, S.T. 1995. Penilaian Organo- leptik (untuk Industri Pangan dan Hasil Pertanian). Bharata Karya Aksara. Jakarta.

Sugito dan A. Hayati. 2006. Penambahan daging ikan gabus (Ophicepallus strianus BLKR) dan aplikasi pembekuan pada pembuatan pempek gluten. Jurnal Ilmu Pertanian Indonesia. 8(2): 147151.

Suyanti, 2008. Membuat Mie Sehat Bergizi dan Bebas Pengawet. Penebar Swadaya. Jakarta.

Talib, A., dan T. Marlena. 2015. Karakteristik organoleptik dan kimia produk empek-empek ikan cakalang. 8 (1): 50-59.

Tanikawa, E. 2000. Marine Product in Japan. Koseisha Koseikaku Co. Ltd. Tokyo.

Trisnawati, R. 2007. Pemanfaatan Surimi Ikan Sapu-Sapu (Hyposarcus pardalis) dalam Pembuatan Empek-Empek. (Skripsi). Institut Pertanian Bogor. Bogor.

Ulfa, I. W. 2018. Pengaruh Perbandingan Tepung Labu Kuning (Curcubita moschate), Tepung Talas (Colocosia esculenta L. Schoott) dan Tepung Terigu Terhadap Karakteristik Makaroni. (Skripsi). Universitas Pasundan. Bandung.

Utomo, D., R. Wahyuni, dan R. Wiyono. 2013. Pemanfaatan ikan gabus (Ophiocephalus striatus) menjadi bakso dalam rangka perbaikan gizi masyarakat dan upaya meningkatkan nilai ekonomisnya. Teknologi Pangan: Media Informasi Dan Komunikasi Ilmiah Teknologi Pertanian. 1(1):3855.

Wijayanti, I., J. Santoso, dan A. M. Jacoeb. 2012. Pengaruh frekuensi pencucian terhadap karakteristik gel surimi ikan lele dumbo (Clarias gariepinus). Jurnal Saintek Perikanan. 8(2): 32-37. 
Yakhin, L.A., K.M. Wijaya, dan J. Santoso. 2015. The effect of seaweed powder (Eucheuma cottonii) addition in catfish sausage. Proceeding of The 1st International Symposium on Aquatic Product Processing. November 2013. Bogor

Yulientin, I. 2006. Penambahan Nilai
Chicken Carcass Meat (CCM) Melalui Pengembangan Produk Baru Perkedel Ayam Berkalsium. (Skripsi). Institut Pertanian Bogor. Bogor. 